\title{
Assessing groundwater quality for irrigation using indicator kriging method
}

\author{
Masoomeh Delbari • Meysam Amiri • \\ Masoud Bahraini Motlagh
}

Received: 18 January 2013/ Accepted: 1 September 2014/Published online: 14 September 2014

(C) The Author(s) 2014. This article is published with open access at Springerlink.com

\begin{abstract}
One of the key parameters influencing sprinkler irrigation performance is water quality. In this study, the spatial variability of groundwater quality parameters (EC, SAR, $\mathrm{Na}^{+}, \mathrm{Cl}^{-}, \mathrm{HCO}_{3}^{-}$and $\mathrm{pH}$ ) was investigated by geostatistical methods and the most suitable areas for implementation of sprinkler irrigation systems in terms of water quality are determined. The study was performed in Fasa county of Fars province using 91 water samples. Results indicated that all parameters are moderately to strongly spatially correlated over the study area. The spatial distribution of $\mathrm{pH}$ and $\mathrm{HCO}_{3}{ }^{-}$was mapped using ordinary kriging. The probability of concentrations of EC, SAR, $\mathrm{Na}^{+}$and $\mathrm{Cl}^{-}$exceeding a threshold limit in groundwater was obtained using indicator kriging (IK). The experimental indicator semivariograms were often fitted well by a spherical model for SAR, EC, $\mathrm{Na}^{+}$and $\mathrm{Cl}^{-}$. For $\mathrm{HCO}_{3}{ }^{-}$and $\mathrm{pH}$, an exponential model was fitted to the experimental semivariograms. Probability maps showed that the risk of EC, SAR, $\mathrm{Na}^{+}$and $\mathrm{Cl}^{-}$exceeding the given critical threshold is higher in lower half of the study area. The most proper agricultural lands for sprinkler irrigation implementation were identified by evaluating all
\end{abstract}

\footnotetext{
M. Delbari $(\bowtie)$

Department of Water Engineering, Faculty of Water and Soil, University of Zabol, Zabol, Iran

e-mail: mas_delbari@yahoo.com
}

\section{Amiri}

Scientific Staff in the Department of Water Resources, International Hamoun Wetland Research Institute, University of Zabol, Zabol, Iran

\section{B. Motlagh}

Graduated Student of Water Resources Engineering, Department of Water Engineering, Faculty of Water and Soil, University of Zabol, Zabol, Iran probability maps. The suitable areas for sprinkler irrigation design were determined to be 25,240 hectares, which is about 34 percent of total agricultural lands and are located in northern and eastern parts. Overall the results of this study showed that IK is an appropriate approach for risk assessment of groundwater pollution, which is useful for a proper groundwater resources management.

Keywords Groundwater quality - Geostatistics · GIS · Probability map $\cdot$ Sprinkler irrigation

\section{Introduction}

Iran is located in arid and semi-arid part of the world and its water resources are in a critical condition. In Iran, the average annual rainfall is less than $250 \mathrm{~mm}$, which is less than one-third of the average rainfall in the world $(800 \mathrm{~mm})$. The average annual evaporation is about $2,100 \mathrm{~mm}$ and it is almost three times the world's average annual evaporation $(700 \mathrm{~mm})$. Iran's population is approximately one percent of the world population, while its share of total renewable water resources of the world is only 0.36 percent. Moreover, the spatial and temporal distribution of rainfall is not uniform; $70 \%$ of rainfall is distributed over $25 \%$ of the country (Alizadeh 2004). In addition, most of the rainfall occurs in non-irrigation seasons. So, groundwater resources play a key role in irrigation of arid and semi-arid agricultural lands. However, the suitability of groundwater quality for irrigation purposes requires to be considered in the beginning for a sustainable utilization of groundwater. Groundwater quality could be influenced by different sources of pollution such as domestic waste water, urban runoff, intensive application of fertilizers and solid waste disposal (Hammouri and El- 
Naqa 2008). On the other hand, most agricultural areas are irrigated by traditional surface irrigation methods while their irrigation efficiency never exceeds $35 \%$ (Alizadeh 2004). To improve irrigation efficiency and to increase water use efficiency in agriculture, a considerable budget has been allocated for agricultural sector to adapt modern irrigation systems effective from 2010. Often, the farmers pay only $15 \%$ of the costs for implementation of sprinkler irrigation system, and the remaining $85 \%$ of costs is paid by the government. With the modern irrigation methods however, the water quality should be carefully controlled to prevent water applicator clogging or water distribution equipments' damage. In addition, utilization of polluted irrigation water deteriorates soil physical properties and reduces the crop yield (Shainberg and Oster 1978; Solomon 1985; Lauchli and Epstein 1990; Shahalam et al. 1998). Therefore to achieve a more effective conservation of natural resources, agricultural management of soils and water becomes essential (Delgado et al. 2010).

The main water characteristics which determine the suitability of ground water for irrigation according to United States Salinity Laboratory (USSL 1954) include: (1) total concentration of soluble salts; (2) relative ratio of sodium to other cations $\left(\mathrm{Mg}^{2+}, \mathrm{Ca}^{2+}\right.$ and $\left.\mathrm{K}^{+}\right)$(3) concentration of boron, chloride or other toxic elements and (4) under some conditions, carbonate or bicarbonate concentrations that is associated with $\mathrm{Ca}^{2+}$ and $\mathrm{Mg}^{2+}$ concentrations. Both physical and chemical qualities of water are important in irrigation systems performance. With sprinkler irrigation in which water sprayed over the plants, low quality of water may cause severe damage, such as leaf burn (Keller and Bliesner 1990). Most trees are sensitive to even relatively low concentrations of sodium and chloride. Increase in bicarbonate concentration of irrigation water in sprinkler irrigation causes white spots on leaves or fruits. An increase in calcium carbonate of irrigation water in drip irrigation causes precipitation of particles and emitter clogging (Shatnawi and Fayyad 1996).

Point data are usually inadequate to identify vulnerable areas, so appropriate interpolation methods are needed to map the spatial distribution pattern of groundwater quality parameters. In contract to traditional interpolation methods which are unable to map uncertainty of the predicted values, geostatistical-based algorithms can be used to assess the uncertainty attached to the estimated values for incorporating in decision making (Van Meirvenne and Goovaerts 2001). Several studies have been done to investigate spatial variability of groundwater quality using geostatistics. Cooper and Istok (1988) utilized kriging for estimation of groundwater contaminants at the Chem-Dyne Superfund site in Ohio. Istok et al. (1993) used cokriging to estimate herbicide concentration of groundwater in an agricultural region. The auxiliary variable was nitrate concentration which was deemed to be more easily available at larger sample size. Indicator kriging is a non-parametric geostatistical estimation method, which has the ability to produce probability maps in which the probability of any soil and water pollutant being larger or smaller than a given threshold value is provided (Goovaerts 1997; Cullmann and Saborowski 2005). Indicator kriging has been used frequently for studying the risk of soil or groundwater contamination (Juang and Lee 2000; van Meirvenne and Goovaerts 2001; Goovaerts et al. 2005; Jang et al. 2010). Indicator kriging was used by Liu et al. (2004) to assess arsenic contamination in an aquifer in Yun-Lin, Taiwan. Goovaerts et al. (2005) studied the spatial variability of arsenic in groundwater in southeast Michigan using indicator kriging. Dash et al. (2010) used indicator kriging to assess the probability of exceedence of groundwater quality parameters e.g. $\mathrm{EC}, \mathrm{Cl}^{-}$ and $\mathrm{NO}_{3}{ }^{-}$in Delhi, India. Ordinary and indicator kriging were used by Adhikary et al. (2010) for mapping groundwater pollution in India. They evaluated the spatial variability of $\mathrm{Ca}^{2+}, \mathrm{Cl}^{-}, \mathrm{HCO}_{3}{ }^{-}, \mathrm{EC}, \mathrm{Na}^{+}, \mathrm{SO}_{4}{ }^{2-}, \mathrm{Mg}^{2+}$ and $\mathrm{NO}_{3}{ }^{-}$and produced pollution risk maps for these parameters. In another study, Adhikary et al. (2011) used indicator and probability kriging methods for delineating $\mathrm{Cu}, \mathrm{Fe}$, and Mn contamination in groundwater in Delhi, India. Piccini et al. (2012) illustrated an application of indicator kriging for mapping the probability of exceeding nitrate contamination thresholds in Central Italy.

The aim of this study was to evaluate the potential of the groundwater to cause crop problems through toxicity, salinity and soil infiltration rate for determining the suitability of groundwater for sprinkler irrigation uses. For this, the spatial variability of groundwater quality parameters in Fasa county of Fars province was investigated using geostatistical tools. Ordinary and indicator kriging were used to map the spatial distribution and the probability of exceeding a critical threshold for some water contaminants.

\section{Materials and methods}

\section{Description of study area}

Fasa county in southern Iran lies between $53^{\circ} 19^{\prime}$ and $54^{\circ}$ $15^{\prime}$ east longitude and $28^{\circ} 31^{\prime}$ and $29^{\circ} 24^{\prime}$ north latitude (Fig. 1). This county is surrounded by the counties of Shiraz and Estahban from the north, by the counties of Jahrom and Zarindasht from the south, by the counties of Darab and Estahban from the east and by the counties of Shiraz and Jahrom from the west. The 30-year average rainfall is $285.6 \mathrm{~mm}$, the average air temperature is $18{ }^{\circ} \mathrm{C}$ and the average annual evaporation is $2,610 \mathrm{~mm}$. The elevation from the sea level generally decreases from the north to the south; the central and southern parts of the 


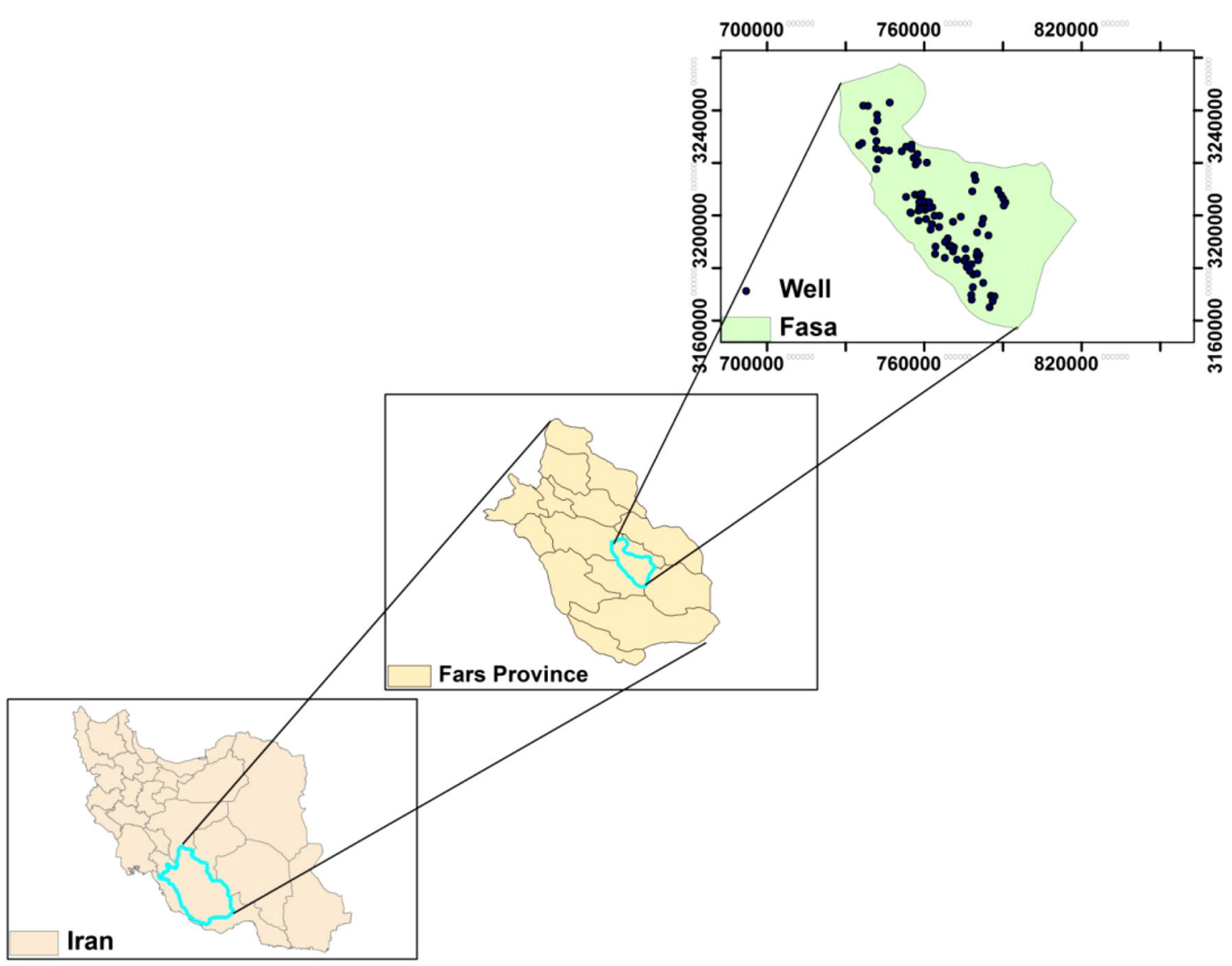

Fig. 1 Location map of study area and observation wells

region have the lowest elevation, while the northern parts are surrounded by mountains. The highest and lowest elevations over the study area are 3,172 and $1,117 \mathrm{~m}$ from free sea level, respectively.

In recent years, due to successive droughts, the government's macro policies in agricultural sector have focused on the implementation of modern irrigation systems. Each year, large public subsidies are allocated to this sector. Sprinkler irrigation systems have gained more attention in the study area from 2000 to 2010. From 2007, however, the implementation rate of sprinkler irrigation has increased with the greater slope, which may be due to higher subsidies $(50 \%)$. From 2010 onwards, the farmers pay only $15 \%$ of the cost for implementation of sprinkler irrigation systems, and the remaining $85 \%$ of the cost is paid by the government; so sprinkler irrigation systems are expected to be more welcome. Based on the land use map (Fig. 2), the study area consists of farm lands, forest, pasture and dry lands. The sprinkler irrigation systems are supposed to be implemented in agricultural lands (dry and irrigated lands), which cover about 74,032 hectares of the whole area.

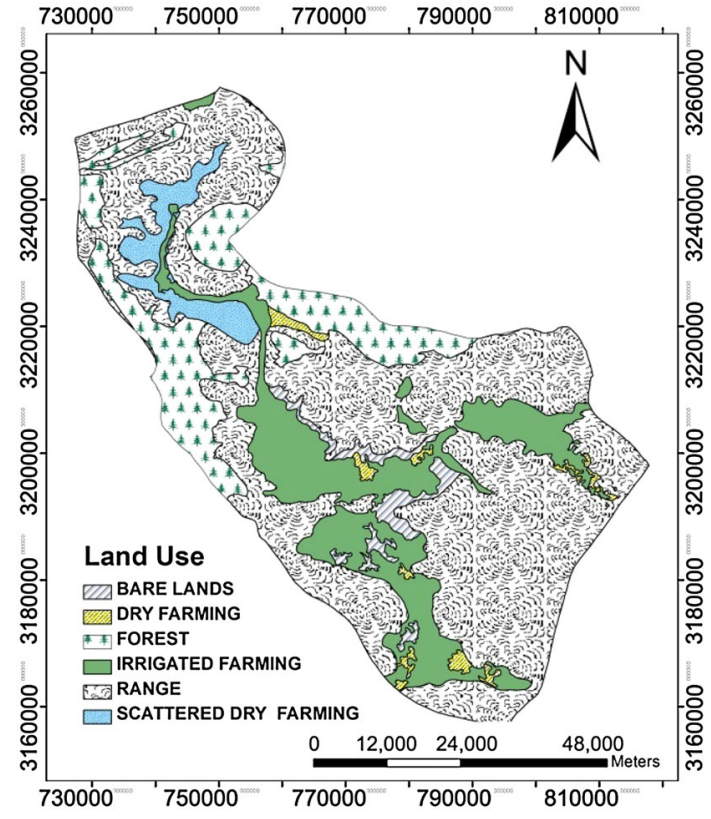

Fig. 2 Land use map of the study area 
Groundwater sampling and analysis

In this study, groundwater quality data from 91 observation wells obtained in 2011 were used for the analysis. The location of the observation wells are shown in Fig. 1. Groundwater samples were analyzed for chemical parameters including $\mathrm{pH}, \mathrm{Na}^{+}, \mathrm{Cl}^{-}, \mathrm{HCO}_{3}{ }^{-}$, electrical conductivity (EC) and sodium absorption ratio (SAR) by adapting the standard procedures of water analysis.

The evaluation of water quality is a fundamental requirement for implementation of modern irrigation systems. Richards (USSL 1954) proposed a table for the classification of irrigation water based on EC and SAR. He also presented a diagram for the classification of irrigation water. Today there are many other ways for the classification of irrigation water but generally, the specified limit for all of these methods is nearly identical. One of the important water quality standards for the sprinkler irrigation systems that has been used in this study (Table 1) is provided by Ayers and Westcot (1994).

Geostatistical analysis

A geostatistical analysis including the investigation of spatial autocorrelation and the interpolation of attribute values at unsampled locations is performed in this study. Spatial autocorrelation analysis describes spatial continuity based on a experimental semivariogram. The experimental semivariogram, $\gamma^{*}(h)$, can be defined as one-half the variance of the difference between the attribute values at all points separated by $h$ as follows: (Isaaks and Srivastava 1989; Goovaerts 1997):

$\gamma^{*}(h)=\frac{1}{2 N(h)} \sum_{i=1}^{N(h)}\left\{Z\left(x_{i}\right)-Z\left(x_{i}+h\right)\right\}^{2}$ where $Z\left(x_{i}\right)$ and $Z\left(x_{i}+h\right)$ are the measured values at locations $x_{i}$ and $x_{i}+h$, respectively. $N(h)$ is the number of pairs of data separated by vector $h$. After calculating experimental semivariogram, a theoretical model should be fit to the experimental data. The type of model and its characteristics are used in kriging system to interpolate the desired variable. The most common types of semivariogram models are spherical, exponential and Gaussian (Isaaks and Srivastava 1989).

To investigate the spatial variability of groundwater quality parameters, the experimental semivariograms of the selected parameters are calculated in four directions 0,45 , 90 and $135^{\circ}$ with an angle tolerance of $22.5^{\circ}$.

\section{Ordinary kriging}

Ordinary kriging (OK) estimator so called "the best linear unbiased estimator (BLUE)"; is defined as follows (Journel and Huijbregts 1978):

$Z^{*}\left(x_{0}\right)=\sum_{i=1}^{n} \lambda_{i} \cdot Z\left(x_{i}\right) \quad$ with $\sum_{i=1}^{n} \lambda_{i}=1$

where $Z^{*}\left(x_{0}\right)$ is the estimated value at unsampled location $x_{0}, \lambda_{i}$ is the weight assigned to the measured value $Z\left(x_{i}\right)$ and $n$ is the number of neighboring points. OK weights $\lambda_{i}$ are allocated to the known values in such that they sum to unity (unbiaseness constraint) and they minimize the kriging estimation variance. The weights are determined by solving the following system of equations (Isaaks and Srivastava 1989):

$\left\{\begin{array}{l}\sum_{j=1}^{n} \lambda_{j} \gamma\left(x_{i}, x_{j}\right)+\mu=\gamma\left(x_{i}, x_{0}\right), \quad i=1, \ldots, n \\ \sum_{j=1}^{n} \lambda_{j}=1\end{array}\right.$

Table 1 Threshold limits for some irrigation water quality parameters (Ayers and Westcot 1994)

\begin{tabular}{|c|c|c|c|c|c|c|}
\hline \multirow[t]{2}{*}{ Irrigation problem } & & & \multirow[t]{2}{*}{ Unit } & \multicolumn{3}{|c|}{ Degree of restriction on use } \\
\hline & & & & None & Slight to moderate & Severe \\
\hline Salinity (EC) & & & $\mathrm{dS} / \mathrm{m}$ & $<0.7$ & $0.7-3.0$ & $>3$ \\
\hline $\mathrm{Na}^{+}$ & & & $\mathrm{meq} / \mathrm{L}$ & $<3$ & $3-9$ & $>9$ \\
\hline $\mathrm{Cl}^{-}$ & & & $\mathrm{meq} / \mathrm{L}$ & $<3$ & $>3$ & \\
\hline \multicolumn{7}{|l|}{ Infiltration } \\
\hline \multirow[t]{5}{*}{$\mathrm{SAR}=$} & $0-3$ & And $\mathrm{EC}=$ & & $>0.7$ & $0.7-0.2$ & $<0.2$ \\
\hline & $3-6$ & & & $>1.2$ & $1.2-0.3$ & $<0.3$ \\
\hline & $6-12$ & & & $>1.9$ & $1.9-0.5$ & $<0.5$ \\
\hline & $12-20$ & & & $>2.9$ & $2.9-1.3$ & $<1.3$ \\
\hline & $20-40$ & & & $>5.0$ & $5.0-2.9$ & $<2.9$ \\
\hline $\mathrm{HCO}_{3}^{-}$ & & & $\mathrm{meq} / \mathrm{L}$ & $<1.5$ & $1.5-8.5$ & $>8.5$ \\
\hline $\mathrm{pH}$ & & & - & & Normal range $6.5-8.4$ & \\
\hline
\end{tabular}

$E C$ electrical conductivity, $S A R$ sodium absorption ratio 
where $\gamma\left(x_{i}, x_{j}\right)$ is the average semivariance between all pairs of data locations; $\mu$ is the Lagrange parameter for the minimization of kriging variance and $\gamma\left(x_{i}, x_{0}\right)$ is the average semivariance between the location to be estimated $\left(x_{0}\right)$ and the $i$ th sample point.

OK also provides a measure of uncertainty attached to each estimated value through calculating the OK variance:

$\sigma^{2}\left(x_{0}\right)=\sum_{i=1}^{n} \lambda_{i} \gamma\left(x_{i}, x_{0}\right)+\mu$

This estimation variance may be used to generate a confidence interval for the corresponding estimate assuming a normal distribution of errors (Goovaerts, 1997).

\section{Indicator kriging}

Instead of real data, IK works with binary variable called "indicator variable". An indicator variable can only takes the values of zero or one considering some threshold values. For a continuous variable $Z\left(x_{i}\right)$, the indicator variable $I\left(x_{i} ; z_{k}\right)$ where $z_{k}$ is the desired threshold limit is defined as follows (Goovaerts 1997):

$I\left(x_{i} ; z_{k}\right)=\left\{\begin{array}{ll}1 & \text { if } Z\left(x_{i}\right) \leq z_{k} \\ 0 & \text { otherwise }\end{array}, \quad k=1, \ldots, K\right.$

where $K$ is the number of cutoffs. The experimental indicator semivariogram, $\gamma_{I}^{*}(h)$, is then defined for every set of indicators at each cutoff $z_{k}$ as:

$\gamma_{I}^{*}(h)=\frac{1}{2 N(h)} \sum_{i=1}^{N(h)}\left[I\left(x_{i} ; z_{k}\right)-I\left(x_{i}+h ; z_{k}\right)\right]^{2}$

where $N(h)$ is the number of pairs of indicator transforms $I\left(x_{i} ; z_{k}\right)$ and $I\left(x_{i}+h ; z_{k}\right)$ separated by vector $h$. The conditional cumulative distribution function (ccdf) at location $x_{0}$ is then obtained by the IK estimator as follows:

$F\left(x_{0} ; z_{k} \mid(n)\right)=I *\left(x_{0} ; z_{k}\right)=\sum_{i=1}^{n} \lambda_{i} I\left(x_{i} ; z_{k}\right)$

where $I^{*}\left(x_{0} ; z_{k}\right)$ is the estimated indicator value at unsampled location $x_{0}$ and $\lambda_{i}$ is the weight assigned to the known indicator value $I\left(x_{i} ; z_{k}\right)$. These discrete probability functions must be interpolated within each class (between every two parts of ccdf) and extrapolated beyond the minimum and maximum values to provide a continuous ccdf covering all the possible ranges of the property of interest (Goovaerts 1997). Local uncertainty measures, e.g., conditional variance and probability of exceeding or not exceeding a given threshold, are provided through post processing of IKbased ccdf's.
Semivariogram analysis of (binary) data and OK is performed using the software (GS + (Gamma Design Software) 2006). IK is implemented using SGeMS (Remy et al. 2009). The software package ArcGIS 9.0 (ESRI (Environmental Systems Research Institute Inc) 2004) with Geostatistical Analyst Extensions is used for mapping.

\section{Results and discussion}

Statistical analysis

The summary statistics of EC, SAR, $\mathrm{Cl}^{-}, \mathrm{Na}^{+}, \mathrm{HCO}_{3}{ }^{-}$and $\mathrm{pH}$ and data are presented in Table 2 . The maximum value of $\mathrm{pH}$ and $\mathrm{HCO}_{3}{ }^{-}$is less than the irrigation water threshold values given in Table 1 and from this perspective, there is no limitation in using groundwater for sprinkler irrigation over the study area. Comparing the mean and maximum values of $\mathrm{SAR}, \mathrm{Na}^{+}, \mathrm{EC}$ and $\mathrm{Cl}^{-}$with the threshold values given in Table 1 indicate that most restrictions are related to the high level of SAR and $\mathrm{Cl}^{-}$and $\mathrm{Na}^{+}$concentrations in the groundwater. The frequency distribution of water quality data (not shown) shows that $59 \%$ of $\mathrm{Cl}^{-}, 57 \%$ of $\mathrm{Na}^{+}, 26 \%$ of SAR and $23 \%$ of EC data values exceed their corresponding irrigation water threshold limits. The maximum concentrations of $\mathrm{Na}^{+}(48.5 \mathrm{meq} / \mathrm{L}), \mathrm{Cl}^{-}$ $(92.5 \mathrm{meq} / \mathrm{L})$ and EC $(13.59 \mathrm{dS} / \mathrm{m})$ are seen in the southern part of the study area with the lowest topographical elevation. High levels of SAR values are seen in south as well as north of the study region.

ArcHydro tool in GIS is used to produce the waterways network by using a digital elevation model (DEM) of the study area. It has been found that water moves from the north to the south so it can be said that use of pesticides and chemical fertilizers on the upstream farms reduces the downstream water quality. These pollutants are transmitted through surface runoff and groundwater toward low elevated parts in south and decrease the quality of water there.

Geostatistical analysis

The results of semivariogram analysis show no considerable anisotropy so the isotropic semivariogram is used for further analysis. The experimental (indicator) semivariogram of the quality parameters are computed and fitted with the best theoretical semivariogram model. For EC, SAR, $\mathrm{Na}^{+}$and $\mathrm{Cl}^{-}, 5$ indicator cutoffs corresponding to $0.10,0.25,0.50,0.75$ and 0.90 quantiles of observed data were selected. The properties of the best fitted model in terms of the lowest residual sum of squares (RSS) and the highest $\mathrm{R}^{2}$ has been presented in Table 3. Meanwhile a cross-validation analysis is performed to confirm the semivariogram model types selected. The best indicator 
Table 2 Descriptive statistics of groundwater quality parameters

\begin{tabular}{|c|c|c|c|c|c|c|}
\hline Parameter & Minimum & Maximum & Mean & Standard deviation & Skewness & Kurtosis \\
\hline $\mathrm{EC}(\mathrm{dS} / \mathrm{m})$ & 0.35 & 13.59 & 2.28 & 2.16 & 2.33 & 7.85 \\
\hline SAR & 0.28 & 11.32 & 2.23 & 1.98 & 2.06 & 6.00 \\
\hline $\mathrm{Cl}^{-}(\mathrm{meq} / \mathrm{L})$ & 0.45 & 92.50 & 9.11 & 13.04 & 3.74 & 19.24 \\
\hline $\mathrm{Na}^{+}(\mathrm{meq} / \mathrm{L})$ & 0.40 & 48.50 & 7.42 & 9.18 & 2.55 & 7.95 \\
\hline $\mathrm{HCO}_{3}{ }^{-}$(meq/L) & 3.00 & 9.50 & 5.20 & 1.34 & 0.75 & 0.41 \\
\hline $\mathrm{pH}$ & 6.85 & 8.50 & 7.39 & 0.31 & 0.78 & 0.91 \\
\hline
\end{tabular}

$E C$ electrical conductivity, SAR sodium absorption ratio

Table 3 Characteristics of the best model of (indicator) semivariograms for groundwater quality parameters

\begin{tabular}{|c|c|c|c|c|c|c|c|c|}
\hline Groundwater quality parameter & Quantile & Model type & $C_{0}$ & $C_{0}+C$ & $A_{0}(\mathrm{~m})$ & $C /\left(C_{0}+C\right)$ & $R^{2}$ & RSS \\
\hline \multirow[t]{5}{*}{$\mathrm{EC}(\mathrm{dS} / \mathrm{m})$} & 0.1 & Spherical & 0.0125 & 0.12 & 35,020 & 0.899 & 0.765 & $3.52 \mathrm{E}-03$ \\
\hline & 0.25 & Spherical & 0.0903 & 0.23 & 38,990 & 0.612 & 0.845 & $3.45 \mathrm{E}-03$ \\
\hline & 0.5 & Spherical & 0.115 & 0.30 & 49,400 & 0.615 & 0.933 & $2.26 \mathrm{E}-03$ \\
\hline & 0.75 & Spherical & 0.0902 & 0.21 & 43,100 & 0.577 & 0.383 & $2.74 \mathrm{E}-03$ \\
\hline & 0.9 & Exponential & 0.0144 & 0.09 & 8,760 & 0.847 & 0.884 & $2.29 \mathrm{E}-04$ \\
\hline \multirow[t]{5}{*}{ SAR } & 0.1 & Spherical & 0.0398 & 0.1 & 51,000 & 0.604 & 0.746 & $1.09 \mathrm{E}-03$ \\
\hline & 0.25 & Spherical & 0.0747 & 0.22 & 34,800 & 0.656 & 0.841 & $3.22 \mathrm{E}-03$ \\
\hline & 0.5 & Spherical & 0.143 & 0.29 & 49,200 & 0.512 & 0.931 & $1.54 \mathrm{E}-03$ \\
\hline & 0.75 & Exponential & 0.038 & 0.17 & 6,720 & 0.775 & 0.948 & $2.52 \mathrm{E}-03$ \\
\hline & 0.9 & Spherical & 0.019 & 0.09 & 12,510 & 0.781 & 0.736 & $1.36 \mathrm{E}-03$ \\
\hline \multirow[t]{5}{*}{$\mathrm{Cl}^{-}(\mathrm{meq} / \mathrm{L})$} & 0.1 & Spherical & 0.0001 & 0.13 & 38,090 & 0.999 & 0.727 & $6.8 \mathrm{E}-03$ \\
\hline & 0.25 & Spherical & 0.098 & 0.23 & 92,870 & 0.77 & 0.86 & $2.9 \mathrm{E}-03$ \\
\hline & 0.5 & Spherical & 0.12 & 0.32 & 55,500 & 0.625 & 0.934 & $2.55 \mathrm{E}-03$ \\
\hline & 0.75 & Spherical & 0.0844 & 0.21 & 43,100 & 0.599 & 0.923 & $1.32 \mathrm{E}-03$ \\
\hline & 0.9 & Spherical & 0.0001 & 0.08 & 6,510 & 0.999 & 0.785 & $9.50 \mathrm{E}-04$ \\
\hline \multirow[t]{5}{*}{$\mathrm{Na}^{+}($meq/L) } & 0.1 & Spherical & 0.046 & 0.09 & 43,000 & 0.489 & 0.564 & $2.43 \mathrm{E}-03$ \\
\hline & 0.25 & Spherical & 0.101 & 0.201 & 42,000 & 0.498 & 0.809 & $4.49 \mathrm{E}-03$ \\
\hline & 0.5 & Spherical & 0.091 & 0.28 & 45,000 & 0.675 & 0.915 & $6.5 \mathrm{E}-03$ \\
\hline & 0.75 & Spherical & 0.069 & 0.20 & 63,680 & 0.655 & 0.904 & $6.83 \mathrm{E}-04$ \\
\hline & 0.9 & Exponential & 0.001 & 0.091 & 8,730 & 0.989 & 0.476 & $1.59 \mathrm{E}-03$ \\
\hline $\mathrm{HCO}_{3}{ }^{-}(\mathrm{meq} / \mathrm{L})$ & - & Exponential & 0.978 & 2.125 & 6,110 & 0.519 & 0.703 & 0.296 \\
\hline $\mathrm{pH}$ & - & Exponential & 0.053 & 0.035 & 2,480 & 0.851 & 0.608 & $1.73 \mathrm{E}-4$ \\
\hline
\end{tabular}

$C_{0}$ random variance, $C$ structured variance, $A_{O}$ range of influence, $R^{2}$ correlation coefficient, $R S S$ residual sum of squares, $E C$ electrical conductivity, $S A R$ sodium absorption ratio

semivariogram model for EC, $\mathrm{SAR}, \mathrm{Na}^{+}$and $\mathrm{Cl}^{-}$is often spherical and the best semivariogram model for $\mathrm{HCO}_{3}{ }^{-}$ and $\mathrm{pH}$ is exponential. Adhikary et al. (2010) suggested a spherical semivariogram model for $\mathrm{EC}, \mathrm{Na}^{+}, \mathrm{Cl}^{-}$ and $\mathrm{HCO}_{3}{ }^{-}$. The spherical model was also selected for EC, SAR, $\mathrm{Cl}^{-}, \mathrm{Na}^{+}$and $\mathrm{HCO}_{3}^{-}$by Delgado et al. (2010).

The higher the ratio of the structured variance to the total variance, i.e., $\mathrm{C} /\left(\mathrm{C}+\mathrm{C}_{0}\right)$ is, the stronger is the spatial correlation. Accordingly, $\mathrm{Na}$ has the highest within-class spatial correlation while $\mathrm{HCO}_{3}{ }^{-}$has the lowest spatial continuity over the study area. The range of (within-class) spatial correlation is smallest for $\mathrm{pH}$ and highest for $\mathrm{Cl}^{-}$.
The semivariogram characteristics of $\mathrm{pH}$ and $\mathrm{HCO}_{3}{ }^{-}$ (Table 3) are used in OK system to map the spatial distribution of these parameters. The generated maps are shown in Fig. 3. According to the map of $\mathrm{pH}$ spatial distribution, western half of the study area has slightly lower $\mathrm{pH}$ than the eastern half. Figure 3 also shows that $\mathrm{HCO}_{3}{ }^{-}$ values range from 4 to 7.5 (meq/L) over majority of the study area. Small parts in the northeast appear to have $\mathrm{HCO}_{3}{ }^{-}$values of 3-4 (meq/L). Considering the irrigation water limits in Table 1 and Fig. 3 shows no limitation in using groundwater for irrigation in terms of $\mathrm{pH}$ and $\mathrm{HCO}_{3}{ }^{-}$ values. Also shown in Fig. 3, the maps of OK-estimation standard deviation (sd), which measures the uncertainty 

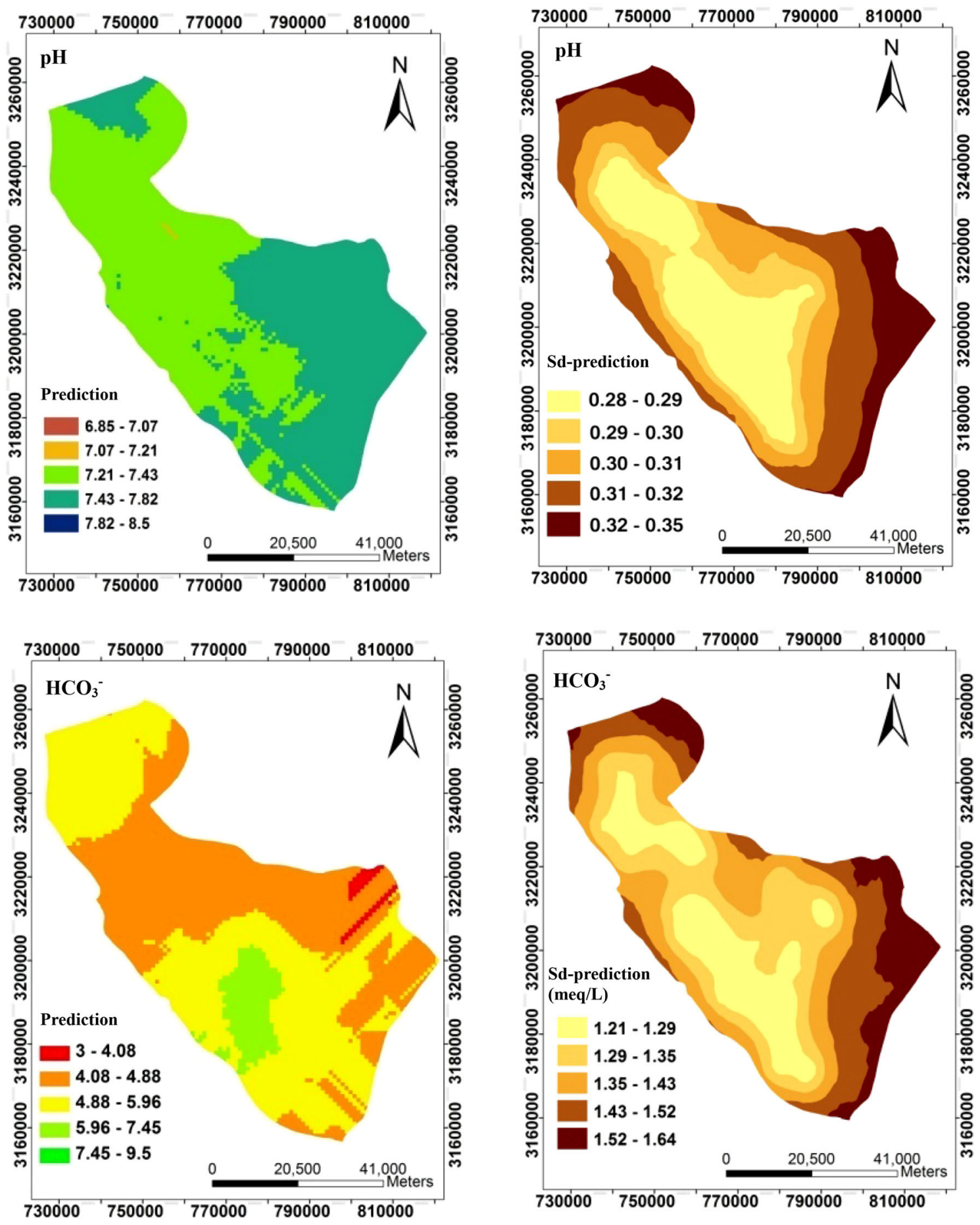

Fig. 3 Maps of spatial distribution and associated standard deviation for $\mathrm{pH}(u p)$ and $\mathrm{HCO}_{3}{ }^{-}$(bottom) produced by $\mathrm{OK}$

associated with the $\mathrm{pH}$ and $\mathrm{HCO}_{3}{ }^{-}$. The estimation error (uncertainty) provided by $\mathrm{OK}$ is smaller at the sampling points and nearby locations and it becomes higher as the distance between the observations is getting larger and where no data are available (northern and eastern parts of the study area).
IK is used to generate the probability map of exceeding $3,3 \mathrm{meq} / \mathrm{L}, 3$ and $3 \mathrm{dS} / \mathrm{m}$, respectively, for $\mathrm{Cl}^{-}, \mathrm{Na}^{+}, \mathrm{SAR}$ and EC (Fig. 4).

For EC, the threshold limit of $3 \mathrm{dS} / \mathrm{m}$ is selected because according to Table 1 , for EC above $3 \mathrm{dS} / \mathrm{m}$, there is severe restriction on use of water for irrigation while for 

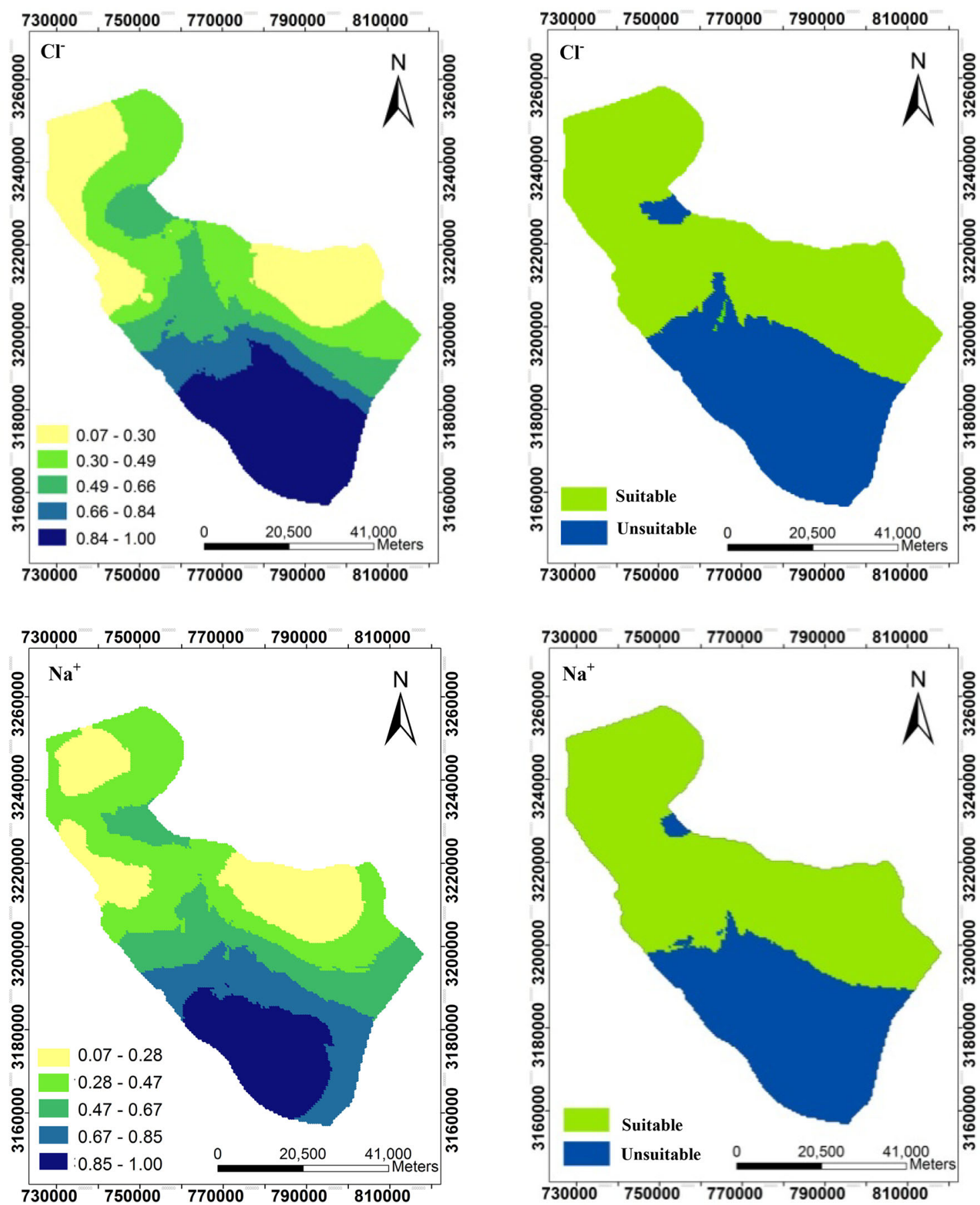

Fig. 4 Probability maps of exceeding 3, 3 meq/L, 3 and $3 \mathrm{dS} / \mathrm{m}$, respectively, for $\mathrm{Cl}^{-}, \mathrm{Na}^{+}$, SAR and EC (left) and classification of groundwater quality into suitable and unsuitable for sprinkler irrigation use based on the probability maps (right)

EC values below $3 \mathrm{dS} / \mathrm{m}$, there is no (where EC is below $0.7 \mathrm{dS} / \mathrm{m}$ ) and a slight to moderate restriction on use. SAR of irrigation water except for a few locations is below 6 , so under this situation according to Ayers and Westcot (1994) if $\mathrm{EC}$ is below $0.3 \mathrm{dS} / \mathrm{m}$, there is a severe restriction on use. As EC of groundwater is above $0.5 \mathrm{dS} / \mathrm{m}$, there is no severe restriction on use. Also for SAR between 0 and 3, in about $90 \%$ of study area, EC of groundwater is above $0.7 \mathrm{dS} / \mathrm{m}$ and therefore there is no restriction on use. For SAR between 3 and 6 , where EC is above $1.2 \mathrm{dS} / \mathrm{m}$, there is no restriction and where EC is between 0.3 and $1.2 \mathrm{dS} /$ $\mathrm{m}$, there is a slight to moderate restriction on use (Ayers and Westcot 1994). Therefore, we used a threshold limit of 3 for SAR. For both $\mathrm{Na}^{+}$and $\mathrm{Cl}^{-}$, a critical limit of $3 \mathrm{meq} /$ 

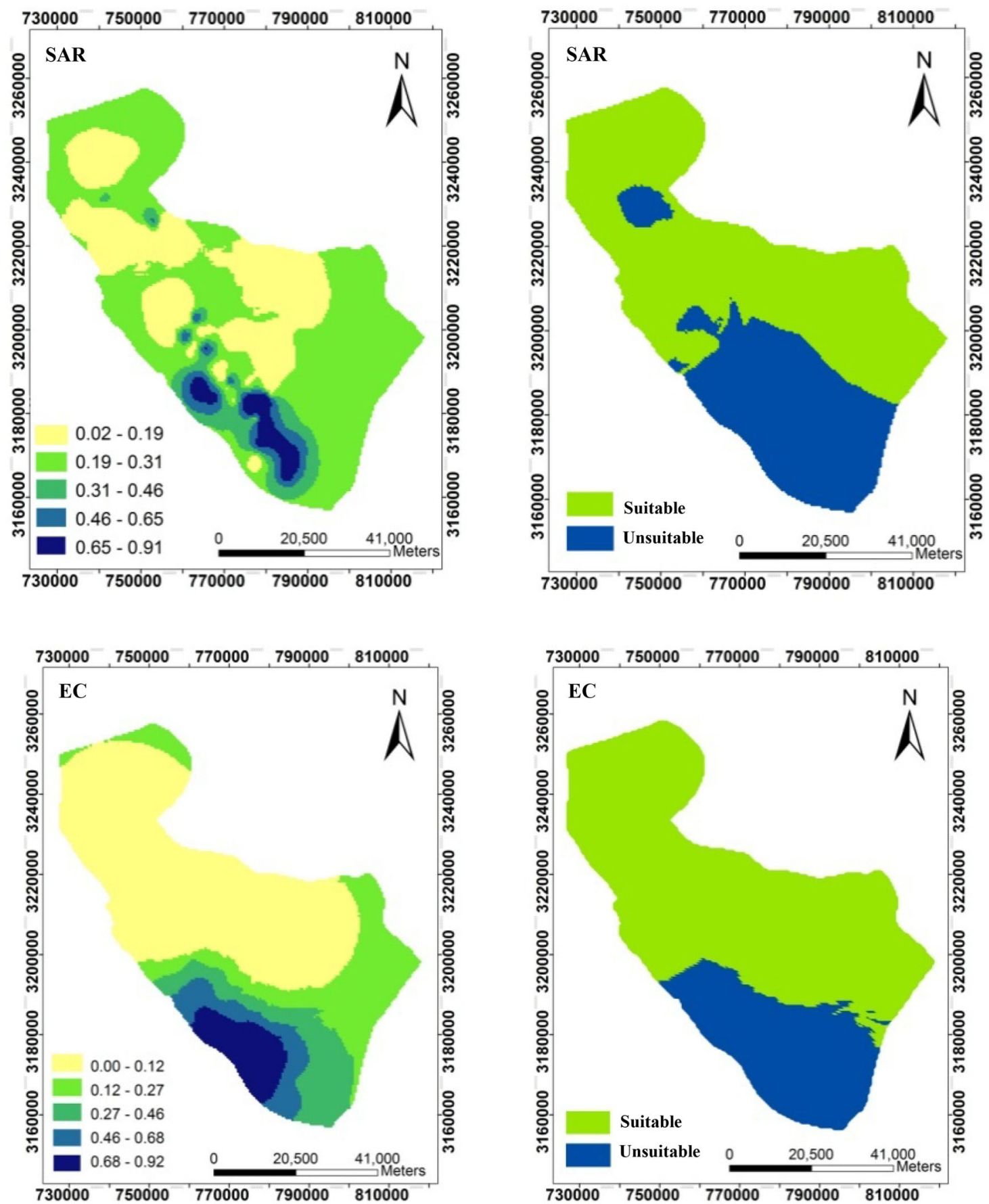

Fig. 4 continued

$\mathrm{L}$ is considered for producing probability maps. According to Ayers and Westcot (1994) there is a slight to moderate restriction on use of irrigation water with $\mathrm{Na}^{+}$and $\mathrm{Cl}^{-}$ above $3 \mathrm{meq} / \mathrm{L}$ for sprinkler irrigation. So the probability maps of exceeding $3 \mathrm{dS} / \mathrm{m}, 3,3 \mathrm{meq} / \mathrm{L}$ and 3 are produced for $\mathrm{EC}, \mathrm{Cl}^{-}, \mathrm{Na}+$ and SAR, respectively.

As shown in Fig. 4, the probability of $\mathrm{Cl}^{-}, \mathrm{Na}^{+}$, SAR and EC exceeding their corresponding critical thresholds is higher in lower half of the study area. Based on probability maps and using the probability threshold, which is assumed to be equal to the marginal probability of each parameter, groundwater quality is classified as suitable and unsuitable for sprinkler irrigation purposes (Fig. 4). According to the maps generated (Fig. 4), the unsuitable groundwater for irrigation in terms of high amounts of $\mathrm{Cl}^{-}, \mathrm{Na}^{+}$, SAR and EC are located in southern parts of the study area. These 


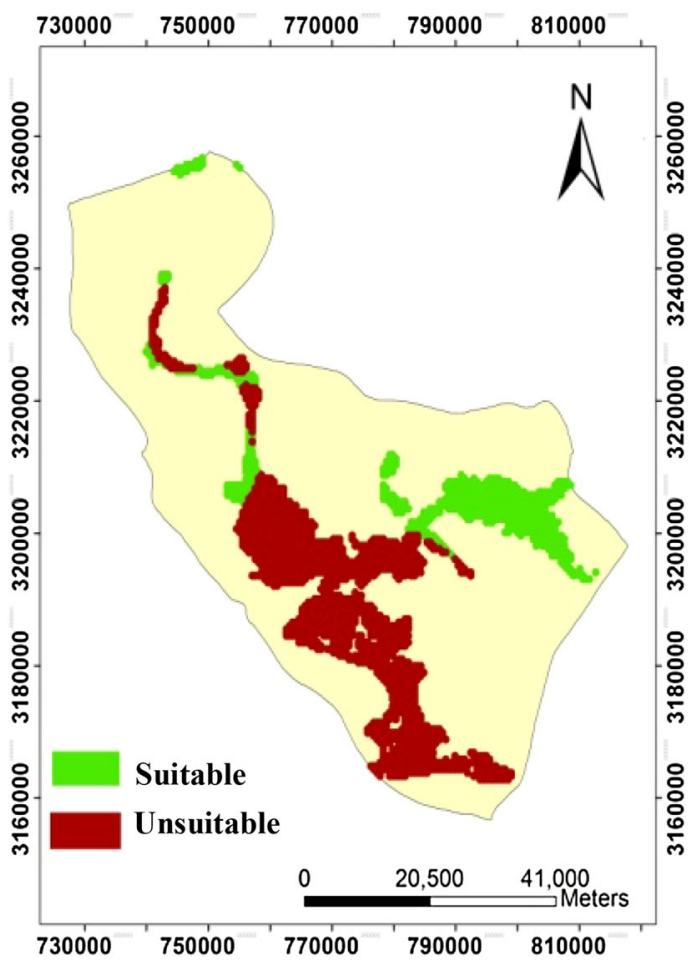

Fig. 5 Classification of groundwater quality into suitable and unsuitable for sprinkler irrigation purpose across the agricultural lands

areas are supposed to be inappropriate for the implementation of sprinkler irrigation. However, the suitability of irrigation water regarding salinity management should be assessed considering salt tolerance of the cultivated crops and soil characteristics. This means in areas with slightly high levels of salinity and sodium, groundwater can still be used for irrigating certain crops e.g. barley, sugar beet and wheat because different crops have different tolerance levels of salinity/sodium hazard (Bauder 2007). Also to reduce leaf burn under sprinkler irrigation from both sodium and chloride, irrigation on cool, cloudy days or overnight would be beneficial. Moreover to avoid direct contact of saline water with leaf surfaces in sprinkler irrigation, drop nozzles and drag hoses are recommended (Bauder 2007).

Considering the classification maps shown in Fig. 4, a single map is produced to show location of suitable and unsuitable groundwater over the study area in terms of all considered groundwater quality parameters across the agricultural lands identified in Fig. 2 (Fig. 5). According to this map, the most suitable areas for sprinkler irrigation system design in terms of water quality are located in north, northwest and east parts of the study area. The appropriate areas for the implementation of the sprinkler irrigation systems are determined to be 25,240 hectares that is about $34 \%$ of total agricultural lands.

\section{Conclusions}

In this study, a geostatistical analysis of EC, SAR, $\mathrm{Na}^{+}$, $\mathrm{Cl}^{-}, \mathrm{HCO}_{3}{ }^{-}$and $\mathrm{pH}$ of groundwater in Fars province, southern Iran is performed and suitability of groundwater for irrigation is assessed. Semivariogram analysis shows that there is a moderate spatial correlation of $\mathrm{HCO}_{3}{ }^{-}$and $\mathrm{pH}$ and a moderate to strong within-class spatial correlation of EC, SAR, $\mathrm{Na}^{+}$and $\mathrm{Cl}^{-}$over the study area. The $\mathrm{pH}$ and $\mathrm{HCO}_{3}{ }^{-}$values are found to be within the permissible limits of standard irrigation water quality. The generated maps of EC, SAR, $\mathrm{Na}^{+}$and $\mathrm{Cl}^{-}$show that water quality decreases from the north to the south of the study area, so the downstream lands have the most polluted groundwater. Thus, the use of groundwater for irrigation in these areas will damage crops and reduce yield. However, more tolerable crops could be cultivated with a good drainage system installation to prevent soil salinization. The most suitable regions for the implementation of the sprinkler irrigation systems are located in northern and eastern parts.

Large investments like sprinkler systems require careful consideration of options before implementation. The results of this study show that a combined utilization of geostatistics and GIS can be useful in decision-making processes such as identifying suitable areas for implementation of the sprinkler irrigation systems and reducing the risk of losing the national capital.

Open Access This article is distributed under the terms of the Creative Commons Attribution License which permits any use, distribution, and reproduction in any medium, provided the original author(s) and the source are credited.

\section{References}

Adhikary PP, Chandrasekharan H, Chakraborty D, Kamble K (2010) Assessment of groundwater pollution in West Delhi, India using geostatistical approach. Environ Monit Assess 167:599-615

Adhikary PP, Dash JCh, Bej R, Chandrasekharan H (2011) Indicator and probability kriging methods for delineating $\mathrm{Cu}, \mathrm{Fe}$, and $\mathrm{Mn}$ contamination in groundwater of Najafgarh Block, Delhi, India. Environ Monit Assess 176:663-676

Alizadeh A (2004) Irrigation water quality. publications Astan Quds Razavi (In Persian)

Ayers RS, Westcot DW (1994) “Water quality for agriculture," Irrigation and drainage Paper 29 Rev. 1 (Reprinted 1989, 1994). Available at http://www.fao.org/DOCREP/003/T0234E/T0234E00.htm

Bauder TA (2007) Colorado State University Extension water quality specialist; Waskom RM, Extension water resource specialist; and Davis JG., Extension soils specialist and professor, soil and crop science

Cooper RM, Istok JD (1988) Geostatistics applied to groundwater contamination. II: application. J Environ Eng, ASCE 114(2):287-299

Cullmann AD, Saborowski J (2005) Estimation of local probabilities for exceeding threshold values in environmental monitoring. Eur J Forest Res 124:67-71 
Dash JP, Sarangi A, Singh DK (2010) Spatial Variability of groundwater depth and quality parameters in the national capital territory of Delhi. Environ Manage 45:640-650

Delgado C, Pacheco J, Cabrera A, Batllori E, Orellana R, Bautista F (2010) Quality of groundwater for irrigation in tropical karst environment: the case of Yucatan, Mexico. Agr Water Manage 97:1423-1433

ESRI (Environmental Systems Research Institute Inc) (2004) ArcGIS 9. Getting Started with ArcGIS. ESRI, Redlands

Goovaerts P (1997) Geostatistics for natural resources evaluation. Oxford University Press, New York

Goovaerts P, AvRuskin G, Meiliker J, Slotnick M, Jacquez G, Nriagu J (2005) Geostatistical modeling of the spatial variability of arsenic in groundwater of southeast Michigan. Water Resour Res 41:1-19

GS + (Gamma Design Software) (2006) Geostatistics for the environmental sciences. GS + User's Guide. Version 7. Plainwell, MI, USA

Hammouri N, El-Naqa A (2008) GIS based hydrogeological vulnerability mapping of groundwater resources in Jerash area-Jordan. Geofisica Int 47:85-97

Isaaks E, Srivastava RM (1989) An introduction to applied geostatistics. Oxford University Press, New York

Istok JD, Smith JD, Flint AL (1993) Multivariate geostatistical analysis of groundwater contamination: a case history. Ground Water 31:63-74

Jang CS, Liou YT, Liang CP (2010) Probabilistically determining roles of groundwater used in aquacultural fishponds. J Hydrol 388:491-500

Journel AG, Huijbregts CJ (1978) Mining geostatistics. London Academic Press, New York 600 p

Juang KW, Lee DY (2000) Comparison of three nonparametric kriging methods for delineating heavy metal contaminated soils. J Environ Qual 29:197-205
Keller J, Bliesner RD (1990) Sprinkle and Trickle Irrigation. Van Nostrand Reinhold, New York. ISBN 0-442-24645-5

Lauchli A, Epstein E (1990) Plant responses to saline and sodic conditions. Agricultural Salinity Assessment and Management Manual, Tanji KK (ed.), ASCE, New York, 113-137

Liu CW, Jang CS, Liao CM (2004) Evaluation of arsenic contamination potential using indicator kriging in the Yun-Lin aquifer (Taiwan). Sci Total Environ 321:173-188

Piccini C, Marchetti A, Farina R, Francaviglia R (2012) Application of indicator kriging to evaluate the probability of exceeding nitrate contamination thresholds. Int J Environ Res 6(4):853-862

Remy N, Boucher A, Wu J (2009) Applied geostatistics with SGeMS: a users' guide. Cambridge University Press, Cambridge

Shahalam A, Abu Zahra BM, Jaradat A (1998) Wastewater irrigation effect on soil, crop and environment: a pilot scale at Irbid, Jordan. Water Air Soil Pollut 106(3/4):425-455

Shainberg I, Oster JD (1978) Quality of irrigation water. IIIC Publication No. 2, Volcani Center, P.O.Box 49, Bet Dagan, Israel, 65 pp. ISBN 92-9019-002-9

Shatnawi M, Fayyad M (1996) Effect of khirbet as-samra treated effluent on the quality of irrigation water in the central Jordan Valley. Water Res 30:2915-2920

Solomon KH (1985) Water-salinity-production functions. Transaction: Am Soc Agr Eng 28: 197.5-19

USSL (1954) Diagnosis and improvement of saline and alkali soils: U.S. Dept. Agr. Handb. 60, 160 p

Van Meirvenne M, Goovaerts P (2001) Evaluating the probability of exceeding a site-specific soil cadmium contamination threshold. Geoderma 102:75-100 